NEW

\title{
ON POWER: THE NATURAL HISTORY OF ITS GROWTH
}

By Bertrand de Jouvenel

With a foreword by D. W. Brogan

Translated by J. F. Huntington

Bertrand de Jouvenel provides us with an analytical and historical account of all of the factors that have helped and continue to help expand the power of the state and of the ways in which state power is inevitably abused. Jouvenel has done for the twentieth century what Tocqueville did for the nineteenth.

-Dr. Nicholas Capaldi, University of Tulsa

On Power demonstrates that modern democracy itself, far from diffusing the power of the state, has given it even greater powers.

$444+$ xxii pages. Foreword, translator's note, index.

Hardcover $\$ 25.00 \quad 0-86597-112-9$

Paperback $\$ 8.50 \quad 0-86597-113-7$

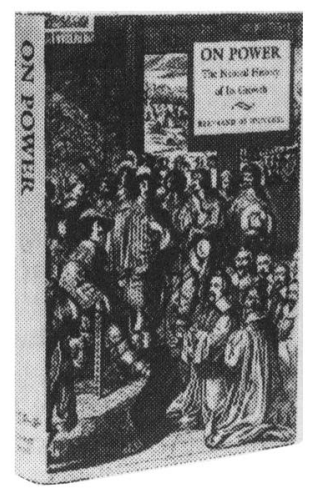

\section{RATIONALISM IN POLITICS AND OTHER ESSAYS}

By Michael Oakeshott

Foreword by Timothy Fuller

"This wonderful new edition of one of the enduring classics of twentieth-century political philosophy introduces to a wider audience the thought of Michael Oakeshott and the dark side of modern rationalism that he so poignantly reveals."

- Michael Allen Gillespie, Duke University

$\begin{array}{lll}\text { Hardcover } & \$ 24.00 & 0-86597-094-7 \\ \text { Paperback } & \$ 7.50 & 0-86597-095-5\end{array}$

To order by phone, call 800-955-8335; fax 317-577-9067. Prepayment by check, VISA, or MasterCard is required on all orders not for resale. We pay book rate postage on orders prepaid by check. Please allow approximately four weeks for delivery.

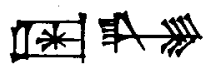




\title{
Books of Note from Penn State Press
}

\section{FAITH AND POLITICAL PHILOSOPHY}

The Correspondence between

\section{Leo Strauss and Eric Voegelin, 1934-1964}

\author{
Translated and edited, with an introduction, \\ by Peter C. Emberley and Barry Cooper
}

In fifty-three recently discovered letters, Strauss and Voegelin explore the nature of their similarities and differences, offering trenchant observations about one another's work, about the state of the discipline, and about the influences working on them. The correspondence fleshes out many assumptions made in their published writings, often with a frankness and directness that remove all vestiges of ambiguity. Included with the correspondence are four pivotal republished essays - Jersualem and Athens: Some Preliminary Reflections (Strauss), The Gospel and Culture (Voegelin), Immortality: Experience and Symbol (Voegelin), and The Mutual Influence of Theology and Philosophy (Strauss) -and commentaries by James L. Wiser, Hans-Georg Gadamer, Stanley Rosen, Thomas J.J. Altizer, Timothy Fuller, Ellis Sandoz, Thomas L. Pangle, and David Walsh.

394 pages $\$ 45.00$

Also of Interest

\section{THE BALANCE OF CONSCIOUSNESS}

\section{Eric Voegelin's Political Theory}

Kenneth Keulman

"This interpretation of the political theory of Voegelin, one of the premier contemporary philosophers of consciousness, history, and social order, amounts to a challenging introduction to his entire enterprise.... Newcomers to Voegelin may find some stretches hard going, but persistence will reward them richly. Old hands will celebrate a fine piece of work."

194 pages $\$ 28.50$

-Religious Studies Review

\section{PENN STATE PRESS}

Barbara Building, Suite $\mathrm{C}$

University Park, PA 16802

MasterCard/VISA orders, call tollfree, 800-326-9180 
William James Booth

Household and Market: On the

Origins of Moral Economic Philosophy

Claudio J. Katz

The Socialist Polis: Antiquity

and Socialism in Marx's Thought

Christopher Bruell

On Plato's Political Philosophy

Cary J. Nederman

The Puzzle of the Political Animal

Gary Remer

Dialogues of Toleration:

Erasmus and Bodin

\section{Review Essays:}

Ernest L. Fortin and Glenn Hughes

The Strauss-Voegelin Correspondence:

Two Reflections and Two Comments

Book Reviews featuring Stephen Worland on Neuhaus and Novak on Capitalism and Catholicism, and Thomas West on Rahe on Republics Ancient and Modern 